\title{
Identification of a gene, closely linked to dnaK, which is required for high-temperature growth of Escherichia coli
}

\author{
DEYRICK O. DEAN and RichaRd JAMES* \\ Molecular/Microbiology Sector, School of Biological Sciences, University of East Anglia, Norwich NR4 7TJ, UK
}

(Received 23 November 1990; revised 15 February 1991; accepted 28 February 1991)

\begin{abstract}
We have constructed four deletion derivatives of the cloned dnaK gene. Plasmid pDD1, in which the last 10 amino acids of the DnaK protein have been replaced by three different amino acids derived from the pBR322 vector, was as effective as plasmid pKP31, from which it was derived, in restoring the ability of a dnaK null mutant, Escherichia coli BB1553, to plate $\lambda$ phage and to grow at high temperatures. The other three mutations, involving much larger deletions of the $d n a K$ gene, did not restore the ability to plate $\lambda$ phage or the ability to grow at high temperatures. Plasmid pKUC2, which contains the whole $d n a K$ gene and its promoters, was capable of restoring the ability of $E$. coli BB1553 to plate $\lambda$ phage but, surprisingly, it did not restore the ability to grow at high temperatures, even though it was shown that the DnaK protein was efficiently expressed in these cultures. By transposon mutagenesis and sub-cloning, we have shown the presence of a second gene in plasmid pKP31 which is required for hightemperature growth of $E$. coli $\mathrm{BB} 1553$. This gene, which we call $h \operatorname{tg} A$, is presumably also defective in the dnaK null mutant $E$. coli $\mathrm{BB1553}$. We have also demonstrated that the inability of $E$. coli $\mathrm{K} 756$ to grow above $43.5^{\circ} \mathrm{C}$ is complemented by sub-clones which contain the $h \operatorname{tg} A$ gene, but not by plasmid pKUC2.
\end{abstract}

\section{Introduction}

Exposure of cells to high temperatures induces the synthesis of a specific group of proteins, known collectively as the heat-shock proteins (for a review see Lindquist \& Craig, 1988). Heat-shock proteins are conveniently subdivided into families according to their molecular mass. One of the most studied of these is the hsp70 family, which includes the $d n a K$-encoded heatshock protein of Escherichia coli. The dnaK gene has been cloned and sequenced (Bardwell \& Craig, 1984); it encodes a protein of $69 \mathrm{kDa}$.The $70 \mathrm{kDa}$ heat-shock proteins appear to be amongst the most highly conserved proteins in nature. The hsp 70 proteins of eukaryotes are extremely difficult to study, since individual cells encode families of similar proteins, which are regulated differently and may have different functions in the cell (Wadsworth, 1982; Ingolia et al., 1982). In contrast, $E$. coli only produces one hsp70-type heat-shock protein, the product of the dnaK gene (Bardwell \& Craig, 1984). Therefore the DnaK protein may perhaps be expected to be a multifunctional protein.

Synthesis of the DnaK protein is inducible, along with 19 other heat-shock proteins in $E$. coli, such that it constitutes $4.3 \%$ of total cell protein at $46^{\circ} \mathrm{C}$ (Herendeen et al., 1979). The induction of heat-shock proteins is dependent upon the product of the $\mathrm{rpoH}$ gene, $\sigma^{32}$, which is required for transcription (Neidhardt \& Van Bogelen, 1981; Yamamori \& Yura, 1982) and regulation (Grossman et al., 1987) of heat-shock genes. The DnaK protein is essential for the growth of $\lambda$ phage in $E$. coli, being required for the initiation of $\lambda$ DNA replication. It appears to be necessary for the dissociation of the DnaB protein from the $\lambda \mathrm{P}$ protein, thereby allowing the action of DNA helicase (Liberek et al., 1988; Zylicz et al., 1989).

The functions of the DnaK protein in E. coli cells are not fully understood. It physically interacts with the GrpE heat-shock protein, both in vitro (Zylicz et al., 1987; Johnson et al., 1989) and in vivo (Johnson et al., 1989). The DnaK protein is reported to be essential for growth of the cells at high and at low temperatures (Paek \& Walker, 1987; Bukau \& Walker, 1989a). The fact that the DnaK protein is also synthesized at $37^{\circ} \mathrm{C}$, where it constitutes $1.4 \%$ of total cell protein (Herendeen et al., 1979), suggests a role for this protein in growth at normal temperatures. dna $K$ mutants of $E$. coli filament readily at non-permissive temperatures, although such mutants rapidly acquire secondary mutations which suppress filamentation (Bukau \& Walker, 1989a). The filamenta- 
tion of dnaK mutants is also suppressed by plasmids that carry the $f t s Z$ gene, which is necessary for normal cell division (Paek \& Walker, 1987). This is perhaps suggestive of a role of the DnaK protein in normal cell division. Recently the DnaK protein was also shown to have a role in mini-F plasmid replication (Ezaki et al., 1989; Kawasaki et al., 1990), in P1 plasmid replication (Bukau \& Walker, 1989b; Tilly \& Yarmolinsky, 1989; Wickner, 1990), and in chromosome segregation (Bukau \& Walker $1989 b$ ).

Our initial objective in this work was to investigate the possible functional domains of the DnaK protein. We have constructed deletion mutants of the cloned dnaK gene. The 'mutant' dnaK genes were then used to complement previously characterized dnaK mutations, in order to determine whether they were able to restore one, or more, of the phenotypic properties of the wildtype $d n a K$ gene.

\section{Methods}

Bacterial strains and media. The strains used in this work are listed in Table 1. All cultures were routinely grown in LB broth, or on plates of LB agar (Miller, 1972), supplemented where required with ampicillin $\left(100 \mu \mathrm{g} \mathrm{ml} \mathrm{m}^{-1}\right)$, chloramphenicol $\left(15 \mu \mathrm{g} \mathrm{ml} \mathrm{ml}^{-1}\right)$, streptomycin $\left(100 \mu \mathrm{g} \mathrm{ml}^{-1}\right)$, or tetracycline $\left(15 \mu \mathrm{g} \mathrm{ml}^{-1}\right)$.

Plasmids. Plasmid pKP31, which contains the complete dnaK gene and its promoters, within a $5 \cdot 3 \mathrm{~kb}$ HindIII fragment cloned into the HindIII site of pBR322, was kindly provided by Graham Walker (Department of Biology, Massachusetts Institute of Technology, USA). The cloning vectors pUC19 (Vieira \& Messing, 1982) and pACYC184 (Chang \& Cohen, 1978) have been previously described. Plasmids constructed in this work are described in the text or in Fig. 1.

Enzymes and reagents. Restriction enzymes and T4 DNA ligase were purchased from Pharmacia/LKB, or NBL.

Plasmid restriction, ligation and electrophoresis. Digestion of DNA with restriction endonucleases, electrophoresis of restriction fragments, ligation of DNA fragments and transformation into $E$. coli JM83 were carried out as described by Maniatis et al. (1982).

Transposon mutagenesis. Transposon mutagenesis of plasmid pK P31 with Tn 1000 was performed as previously described (Chak \& James 1984).

Plasmid transformation into dnaK mutants. Transformation into $E$. coli $\mathrm{BB} 1553$ or $E$. coli $\mathrm{K} 756$ was done by the freeze-thaw method as described by Merrick et al. (1987).

SDS-PAGE and Western blotting. E.coli cultures were grown to an $\mathrm{OD}_{550}$ of between 0.9 and 1.1 at $30^{\circ} \mathrm{C}$, or were grown to an $\mathrm{OD}_{550}$ of 0.6 at $30^{\circ} \mathrm{C}$ before being transferred to $42^{\circ} \mathrm{C}$ until the $\mathrm{OD}_{550}$ reached 0.9 to $1 \cdot 1$. Two-millilitre volumes of these cultures were then centrifuged at $12000 \mathrm{~g}$ for $60 \mathrm{~s}$ and the supernatant completely removed. The cell pellets were resuspended in $100 \mu \mathrm{l}$ loading buffer $(40 \mathrm{~mm}-\mathrm{Tris} / \mathrm{HCl}$ pH 6.8 containing $50 \mathrm{~mm}$-DTT, $1 \%$, w/v, SDS, $7.5 \%$, w/v, glycerol and $0.00015 \%, w / v$, bromophenol blue), boiled for $5 \mathrm{~min}$ and centrifuged again briefly. Twenty-microlitre volumes were then loaded on a $10 \%$ (w/v) SDS-PAGE gel and electrophoresis was carried out in an ATTO electrophoresis system following the protocol recommended by the manufacturer. The SDS-PAGE gels were then either stained for
Table 1. E. coli strains used in this work

\begin{tabular}{|c|c|}
\hline Strain & Genotype/phenotype \\
\hline K756 & dnaK756 derivative of $E$. coli $\mathrm{C} 600$ \\
\hline MC4100 & $\mathrm{Ara}^{-} \Delta(\operatorname{argF}-l a c)$ relAl deoCl ptsF 25 rpsA \\
\hline BB 1553 & $\begin{array}{l}\triangle d n a K 52:: \mathrm{Cm}^{\mathrm{r}} \text { derivative of } \mathrm{MC} 4100 \text { with a sidBl } \\
\text { secondary mutation }\end{array}$ \\
\hline JM83 & $\mathrm{Lac}^{-}$Pro $^{-}$Thi $^{-}$rpsL $\phi 80 \mathrm{~d} l a c Z M 15$ \\
\hline
\end{tabular}

protein with Coomassie blue, or electroblotted for $1 \mathrm{~h}$ at $80 \mathrm{~mA}$ onto nitrocellulose using the Sartoblot II system. The nitrocellulose filters

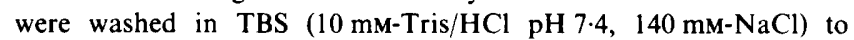
remove excess SDS and then blocked with $2 \%(w / v)$ BSA in TBS. Subsequently the filters were washed for $1 \mathrm{~h}$, with agitation, in $3 \%$ $(w / v)$ BSA in TBS containing a 1 in 10000 dilution of a polyclonal DnaK antibody (kindly provided by Barbara Dalie, Roche Institute of Molecular Biology, Nutley, NJ, USA), and then in $3 \%(w / v)$ BSA in TBS, containing a 1 in 3000 dilution of goat anti-rabbit antibody labelled with horseradish peroxidase (Bio-Rad). The excess antibody in each case was removed by washing for $6 \times 5 \mathrm{~min}$ with TBS. The immunoactive bands were visualized by staining with 4-chloronaphthol.

$\lambda$ phage plating efficiency. Stocks of bacteriophage $\lambda d$ na $K^{+}$and $\lambda$ clear were prepared as previously described (Maniatis et al., 1982). E. coli cultures containing the plasmid being tested were grown up with shaking at $30^{\circ} \mathrm{C}$ overnight in LB broth containing maltose $(0.2 \%, \mathrm{w} / \mathrm{v})$ and $\mathrm{MgSO}_{4}(8 \mathrm{mM})$. Aliquots $(100 \mu 1)$ of each test culture were then mixed with $100 \mu 1$ of a suitable dilution of the $\lambda$ stock suspensions and incubated at $30^{\circ} \mathrm{C}$ for $30 \mathrm{~min}$, to allow phage adsorption, before plating in a soft-agar overlay on LB agar plates containing ampicillin, maltose and $\mathrm{MgSO}_{4}$. After overnight incubation at $30^{\circ} \mathrm{C}$ the plaques were counted and the number of plaques was averaged for the three plates used for each culture. The number of plaques was then expressed as a percentage of the number of plaques found with $\lambda d n a K^{+}$plated on the $E$. coli host containing plasmid pKUC2.

High-temperature growth. Cultures of E. coli K756, or BB1553, carrying recombinant plasmids were grown up overnight at $30^{\circ} \mathrm{C}$ with shaking, and were then streaked onto plates of LB agar containing the required antibiotics. After overnight incubation at $30^{\circ} \mathrm{C}, 42{ }^{\circ} \mathrm{C}$ or $45^{\circ} \mathrm{C}$, the plates were inspected for growth of the streaks. The results were double-checked by restreaking from the $30^{\circ} \mathrm{C}$ plate onto plates which were incubated overnight at $30^{\circ} \mathrm{C}, 42^{\circ} \mathrm{C}$ or $45^{\circ} \mathrm{C}$.

\section{Results}

\section{Construction of deletion mutants of dnaK}

In order to facilitate the construction of in-frame deletion mutants of the dnaK gene, we determined a more detailed restriction map of plasmid pKP31 (Fig. 1). The published nucleotide sequence of the $d n a K$ gene (Bardwell \& Craig, 1984) was also analysed for restriction sites. Plasmid pDD1 was generated from pKP 31 by deletion of the $901 \mathrm{bp} \mathrm{SalI}$ fragment from the 3' end of the dnaK gene to the Sal I site in the vector pBR322 (Fig. 1). The resulting plasmid encoded a mutant protein which consisted of the first 628 of the 638 amino acids of the DnaK protein. The last 10 amino acids of DnaK 

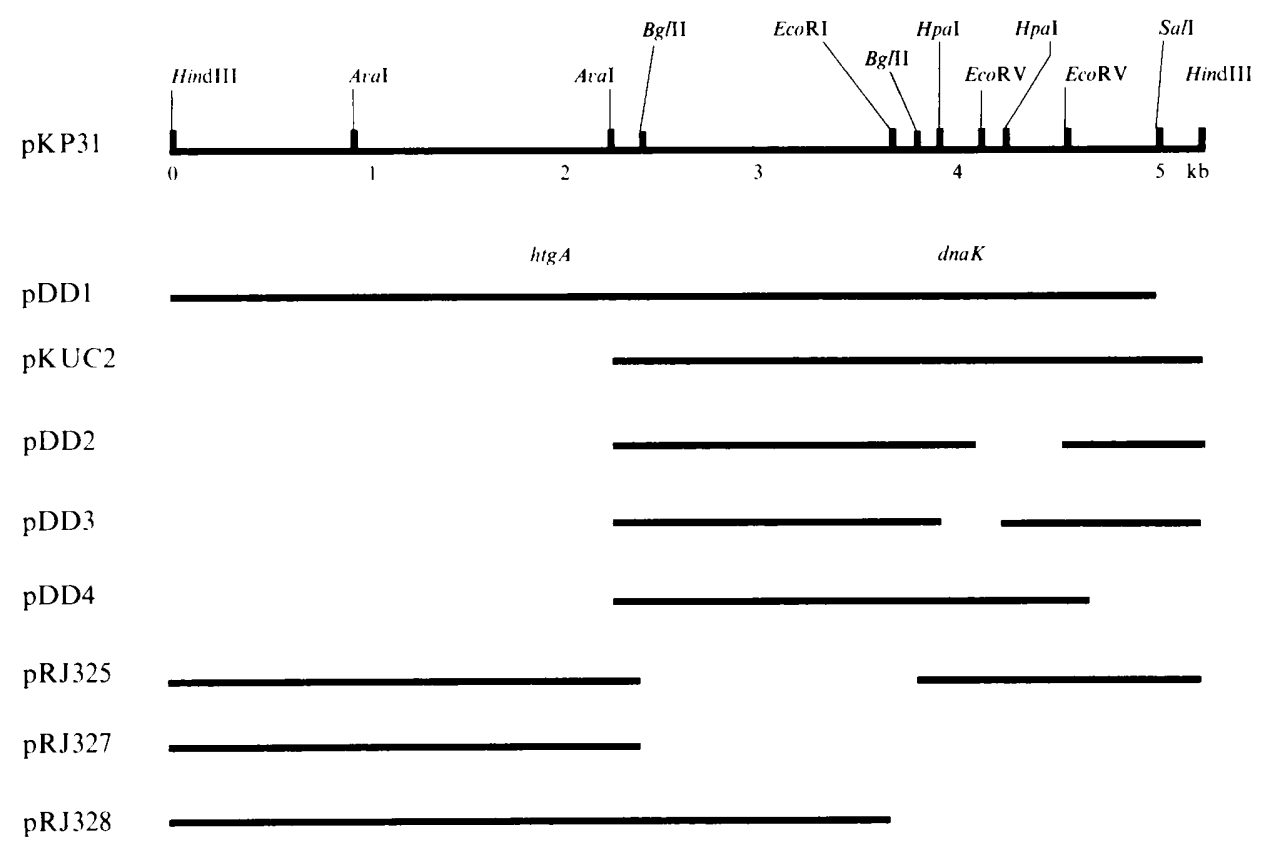

Fig. 1. Subcloning of plasmid pK P31. The restriction sites present in the $5.3 \mathrm{~kb}$ HindIII fragment of pK P31 are indicated in the top line of the figure. The restriction fragments present in the plasmids listed are indicated.

(AEFEEVKDKK) were replaced by three different amino acids (RCP) derived from the vector. The resulting mutant protein therefore consists of 631 amino acids.

Inspection of the restriction map of $\mathrm{pK} P 31$ revealed the presence of an Aval site at approximately $2.3 \mathrm{~kb}$. The $3 \mathrm{~kb}$ AvaI-HindIII fragment which includes the whole of the dnaK gene was sub-cloned in pUC19. The resulting plasmid was designated pKUC2. Two further constructs were derived from pKUC2 by deletion sub-cloning, using either EcoRV, or HpaI. The resulting plasmids, pDD2 and pDD3, contained in-frame, internal deletions of the dnaK gene. In pDD2 the deletion removed 144 amino acids, from 333 to $527(22.6 \%$ of the DnaK protein), whilst in pDD3 the deletion removed 84 amino acids, from 281 to 365 ( $13.2 \%$ of the protein). The final deletion mutant of dnaK, pDD4, was isolated by chance during Tn1000-mediated transposon mutagenesis of pKUC2. Plasmid pDD4 contains a Tn 1000 insert in the dnaK gene $3^{\prime}$ to the EcoRV site at 1431 bp (Fig. 1). It presumably results in a fusion between the dnaK gene and $\operatorname{Tn} 1000$-derived sequences until an in-frame stop codon is reached The resulting plasmid has lost approximately $25 \%$ of the $3^{\prime}$ end of the dnaK gene.

\section{Expression of the mutant DnaK proteins}

In order to demonstrate expression of the DnaK protein in these constructs we used the $d n a K$ null mutant $E$. coli
BB 1553 as the host strain. This strain, which carries the $\triangle d n a K 52:: \mathrm{Cm}^{\mathrm{r}}$ deletion described by Paek \& Walker (1987), also carries a secondary mutation, sidBI, which allows growth at $37^{\circ} \mathrm{C}$ (Bukau \& Walker, 1990). Total cell protein extracts were prepared and run on SDSPAGE gels, which were either stained for protein, or Western blotted using the polyclonal anti-DnaK antibody (Fig. 2). The results clearly show that the size of the truncated DnaK proteins encoded by the deletion mutants were as predicted from the extent of the inframe deletions in the dnaK gene. The relative amounts of the truncated DnaK proteins encoded by pDD2, pDD3 and pDD4 appeared to be significantly less than with the full-size DnaK protein. This may well be due to some proteolytic degradation. Indeed, the Western blot of pDD2 reproducibly yielded two fragments, presumably as a result of degradation of the upper full-size fragment.

\section{Phenotypes of the mutant DnaK proteins}

$\lambda$ phage plating efficiency. E. coli $\mathrm{K} 756$ (Georgopoulos \& Herskowitz, 1971; Saito \& Uchida, 1977), or dnaK null mutants like E. coli BB1553 (Paek \& Walker, 1987), will not support the growth of $\lambda$ phage, due to a defect in DNA initiation. Phage $\lambda d n a K^{+}$will however plate on both of these $E$. coli dnaK mutant strains. The wild-type $d n a K^{+}$gene in either plasmid pKP31 or pKUC2 complemented the dnaK null mutation of E. coli $\mathrm{BB} 1553$ 


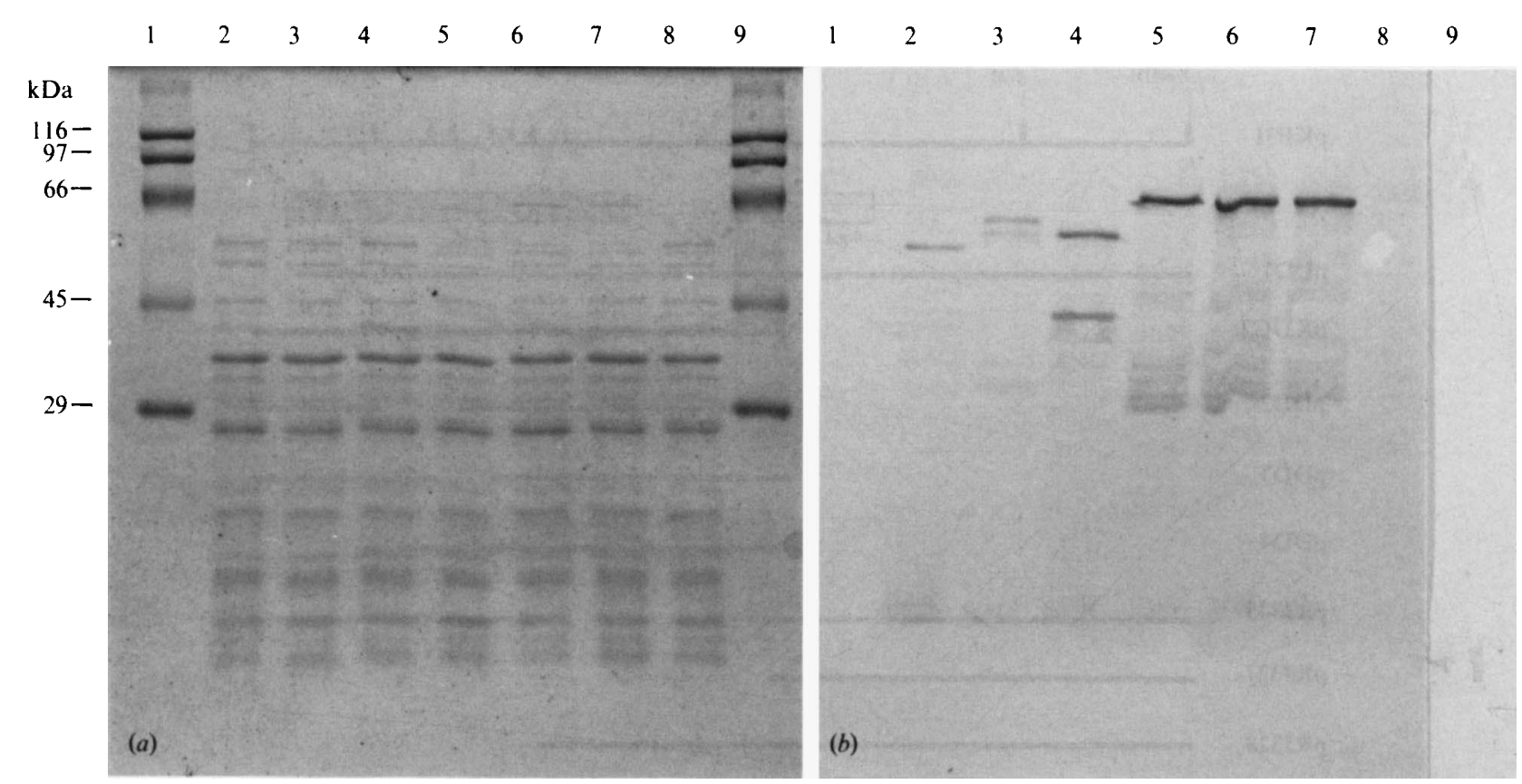

Fig. 2. SDS-PAGE and Western blot of total cell extracts of the $d n a K$ constructs. Total cell extracts of $E$. coli BB 1553 containing pDD4 (lane 2), pDD3 (lane 3), pDD2 (lane 4), pDD1 (lane 5), pKP31 (lane 6), pK UC2 (lane 7) or pBR322 (lane 8), were run on SDS-PAGE gels and then stained for protein $(a)$, or Western blotted with DnaK antibody $(b)$. Lanes 1 and 9 of both gels contained molecular mass markers.

Table 2. Restoration of $\lambda$ plating by cloned dnaK

The phage titres were obtained by plating $\lambda$ clear or $\lambda d n a K^{+}$on either E. coli BB1553 or E. coli K756 containing the plasmid indicated. This experiment was repeated twice with similar results each time.

\begin{tabular}{|c|c|c|c|c|}
\hline \multirow[b]{2}{*}{$\begin{array}{l}\text { Phage } \\
\text { Plasmid }\end{array}$} & \multicolumn{2}{|c|}{ E. coli $\mathrm{BB} 1553$} & \multicolumn{2}{|c|}{ E. coli $\mathrm{K} 756$} \\
\hline & $\lambda$ clear & $\lambda d n a K^{+}$ & $\lambda$ clear & $\lambda d n a K^{+}$ \\
\hline pBR322 & $<0.0008$ & $4 \cdot 5 \pm 2 \cdot 5$ & $0.001 \pm 0.0001$ & $7 \cdot 4 \pm 0 \cdot 8$ \\
\hline pKP31 & $60 \cdot 3 \pm 0 \cdot 49$ & $69 \cdot 1 \pm 4 \cdot 8$ & $54 \cdot 0 \pm 1 \cdot 5$ & $69 \cdot 2 \pm 2 \cdot 1$ \\
\hline pDDI & $68 \cdot 6 \pm 0 \cdot 25$ & $81 \cdot 9 \pm 1 \cdot 6$ & $68 \cdot 8 \pm 7 \cdot 3$ & $74 \cdot 6 \pm 0 \cdot 8$ \\
\hline pUC19 & $<0.0008$ & $2 \cdot 7 \pm 0 \cdot 2$ & $0.000 \overline{9} \pm 0.0001$ & $8.1 \pm 0.7$ \\
\hline pKUC2 & $82 \cdot 6 \pm 6 \cdot 5$ & $100 \pm 3 \cdot 3$ & $90 \cdot 6 \pm 10 \cdot 9$ & $100 \pm 3 \cdot 6$ \\
\hline pDD2 & $<0.0008$ & $28 \cdot 1 \pm 0 \cdot 7$ & $<0.0008$ & $29 \cdot 6 \pm 3 \cdot 5$ \\
\hline pDD3 & $<0.0008$ & $37.9 \pm 1.7$ & $<0.0008$ & $38 \cdot 0 \pm 4.4$ \\
\hline pDD4 & $<0.0008$ & $7 \cdot 1 \pm 0 \cdot 2$ & $<0.0008$ & $11.6 \pm 0.6$ \\
\hline
\end{tabular}

and allowed plating of $\lambda$ phage. It was interesting that the presence of the wild-type gene on these multi-copy plasmids further increased the plating efficiency of $\lambda d n a K^{+}$on $E$. coli $\mathrm{BB} 1553$. This suggests that there is a gene dosage effect of the DnaK protein on phage plating. Plasmid pDD1 restored the ability of E. coli BB1553 to plate $\lambda$ phage to the level seen with plasmid pKP31, from which it is derived (Table 2). This suggests that the last 10 amino acids of the DnaK protein, which are conserved in both E. coli and Bacillus, are not required for initiation of $\lambda$ DNA replication. None of the other mutant $d n a K$ genes restored the ability of $E$. coli $\mathrm{BB} 1553$ to plate $\lambda$ phage (Table 2 ), although both plasmids pDD2 and pDD3 had some effect in increasing the plating efficiency of $\lambda d n a K^{+}$. This perhaps suggests that the DnaK proteins encoded by these constructs retain some activity in the reactions required for $\lambda$ plating on $E$. coli. Similar results were obtained using $E$. coli $\mathrm{K} 756$ as the host strain, except that the actual number of plaques was some 20 fold higher than with E. coli BB1553 (Table 2).

High-temperature growth. Deletions of the dnaK gene in E. coli prevent growth at above $30^{\circ} \mathrm{C}$. E. coli BB 1553 contains a secondary mutation, sid $\mathrm{B} 1$, which allows growth at $37^{\circ} \mathrm{C}$. Plasmid pKP31 restored the ability of $E$. coli BB1553 to grow at either $42^{\circ} \mathrm{C}$ or $45^{\circ} \mathrm{C}$ (Table 3). A similar result was observed with plasmid pDD1. Surprisingly, plasmid pKUC2, which contains the whole dnaK heat-shock gene and its promoters, and which efficiently expresses the DnaK protein (Fig. 2), did not allow growth of $E$. coli $\mathrm{BB} 1553$ at $42^{\circ} \mathrm{C}$. This suggests that the inability of $E$. coli $\mathrm{BB} 1553$ to grow at high temperature is not solely the result of the deletion of the $d n a K$ gene. One possible hypothesis is that there is a mutation, or deletion, in another gene closely linked to dnaK which was introduced during the construction of this dnaK deletion. This possibility is perhaps strengthened by 
Table 3. High-temperature growth of E. coli BB1553 and E. coli $K 756$

E. coli $\mathrm{BB} 1553$, or $E$. coli $\mathrm{K} 756$, transformed with the plasmid shown was tested for its ability to grow at the three temperatures shown. + , Growth; - , no growth; \pm , poor growth. This experiment was repeated three times.

\begin{tabular}{lccccccc}
\hline \hline & \multicolumn{3}{c}{ E. coli BB1553 } & & \multicolumn{3}{c}{ E. coli K756 } \\
\cline { 2 - 4 } \cline { 6 - 8 } Plasmid & $30{ }^{\circ} \mathrm{C}$ & $42{ }^{\circ} \mathrm{C}$ & $45{ }^{\circ} \mathrm{C}$ & & $30{ }^{\circ} \mathrm{C}$ & $42{ }^{\circ} \mathrm{C}$ & $45^{\circ} \mathrm{C}$ \\
\hline None & + & - & - & + & + & - \\
pBR322 & + & - & - & & + & + & - \\
pKP31 & + & + & + & + & + & + \\
pDD1 & + & + & + & & + & + & + \\
pUC19 & + & - & - & & + & \pm & - \\
pKUC2 & + & - & - & + & \pm & - \\
pDD2 & + & - & - & + & \pm & - \\
pDD3 & + & - & - & + & \pm & - \\
pDD4 & + & - & - & + & \pm & - \\
pRJ325 & + & - & - & & + & + & + \\
pRJ327 & + & - & - & & + & \pm & - \\
pRJ328 & + & - & - & + & \pm & - \\
pDD11 & + & - & - & + & + & + \\
pDD12 & + & - & - & + & + & + \\
\hline \hline
\end{tabular}

consideration of the technical details of the derivation of this $d n a K$ null mutant. This involved the replacement of $933 \mathrm{bp}$ at the $5^{\prime}$ end of the dnaK gene, together with some $800 \mathrm{bp}$ of the sequence upstream of the $d n a K$ gene, with a chloramphenicol resistance cassette (Paek \& Walker, 1987). Our results show that the mutation in this hypothetical second gene is complemented by plasmid pKP31, but not by plasmid pKUC2. In order to confirm this hypothesis and to localize this second gene we performed transposon Tn 1000 mutagenesis of plasmid pKP31.

\section{Transposon mutagenesis of $p K P 31$}

Transconjugant colonies of $E$. coli BB1553, containing pKP31 with random $\operatorname{Tn} 1000$ inserts, were screened for their inability to grow at $42{ }^{\circ} \mathrm{C}$. Six independent $\mathrm{Tn} 1000$ inserts were obtained which inactivated the ability of pKP31 to restore high-temperature growth to $E$. coli BB1553; none of them affected $\lambda$ plating. Restriction mapping of the Tn 1000 inserts further confirmed that they are not located in the $d n a K$ gene. The insertions were located between 2.0 and $2.4 \mathrm{~kb}$ from the left-hand HindIII site of pKP31, which is at least 700 bp upstream of the $5^{\prime}$ end of the dnaK gene. Western blots of these cultures revealed that they contain similar amounts of the DnaK protein as cultures containing pKP31 (data not shown). We propose to call the gene inactivated by these $\mathrm{Tn} 1000$ inserts $h \operatorname{tg} A$, for high temperature growth.
Table 4. High-temperature growth of E. coli BB1553 with a binary vector system

E. coli BB1553 containing the plasmid shown in the left-hand column was transformed with either pDD1841 or pACYC184, and representative transformants were then tested for their ability to grow at the three temperatures shown. This experiment was repeated twice with identical results each time.

\begin{tabular}{lccccccc}
\hline \hline & \multicolumn{3}{c}{ pDD1841 } & & \multicolumn{3}{c}{ pAYC184 } \\
\cline { 2 - 4 } \cline { 6 - 8 } Plasmid & $30{ }^{\circ} \mathrm{C}$ & $42{ }^{\circ} \mathrm{C}$ & $45^{\circ} \mathrm{C}$ & & $30{ }^{\circ} \mathrm{C}$ & $42{ }^{\circ} \mathrm{C}$ & $45^{\circ} \mathrm{C}$ \\
\hline None & + & - & - & + & - & - \\
pRJ325 & + & + & + & & + & - & - \\
pD11 & + & + & + & & + & - & - \\
pDD12 & + & + & + & & + & - & - \\
\hline \hline
\end{tabular}

The htgA gene alone does not restore high-temperature growth

In order to investigate whether the $h \operatorname{tg} A$ gene alone, or in combination with $d n a K$, is required for high-temperature growth of $E$. coli $\mathrm{BB} 1553$, we made further recombinani constructs. Plasmid pRJ 327 is the $2 \cdot 1 \mathrm{~kb}$ HindIII-BglII fragment of pKP31 cloned into pUC19, whilst pDD11 is the same fragment cloned into pBR322. Plasmid pRJ328 is the $3.6 \mathrm{~kb}$ HindIII-EcoRI fragment of pKP31 cloned into pUC19, whilst pDD12 is the same fragment cloned into pBR322. None of these four plasmids restored the ability of E. coli BB1553 to grow at either $42^{\circ} \mathrm{C}$ or $45^{\circ} \mathrm{C}$ (Table 3). This result suggests that both the htg $A$ and the $d n a K$ genes are required for high-temperature growth of E. coli. We demonstrated the requirement for both genes by using a binary vector system, using two compatible cloning vectors. Plasmid pDD1841 consists of the $3.0 \mathrm{~kb}$ AvaI-HindIII fragment from pKUC2, which contains the $d n a K$ gene, cloned into pACYC184. This plasmid restored the ability of $E$. coli $\mathrm{BB} 1553$ containing plasmid $\mathrm{pRJ} 325$, pDD11, or $\mathrm{pDD} 12$, to grow at high temperatures (Table 4). The result of this experiment also clearly shows that the dnaK gene present in pKUC2 is not defective in any way.

\section{The DnaK756 heat-shock protein}

E. coli $\mathrm{K} 756$ is capable of growth up to $43.5^{\circ} \mathrm{C}$ (Georgopoulos, 1977), but not at $45^{\circ} \mathrm{C}$. This phenotype has been assumed to be the result of the production of an altered DnaK protein, which has a different pI. Plasmids pRJ325, pDD11 and pDD12 were all capable of restoring growth of this $d n a K$ mutant at $45^{\circ} \mathrm{C}$ (Table 3). This suggests that the inability to grow at high temperatures is the result of a second mutation in $E$. coli $\mathrm{K} 756$, possibly in the $h \operatorname{tg} A$ gene, rather than due to the altered DnaK 756 protein. The DnaK 756 mutant pro- 
tein, although not capable of the functions necessary to allow the plating of $\lambda$ phage, must be able to substitute for the wild-type DnaK protein in its role in hightemperature growth of $E$. coli. An alternative explanation is that the alterations in the DnaK756 protein require a compensating increase in the gene dosage of the $h \operatorname{tg} A$ gene. We are attempting to clone the $h \operatorname{tg} A$ gene from $E$. coli $\mathrm{K} 756$ to distinguish these possibilities.

A comparison of the results in this experiment with plasmids pDD11 and pDD12, which are both recombinant constructs using pBR322 as the vector, and the equivalent constructs in pUC vectors, $\mathrm{pRJ} 327$ and $p R J 328$, reveals an interesting effect (Table 3). The higher-copy-number pUC-based recombinant plasmids, unlike the equivalent pBR322-based constructs, do not restore growth of $E$. coli $\mathrm{K} 756$ at $45^{\circ} \mathrm{C}$. This perhaps suggests that when the $h \operatorname{tg} A$ gene is present in a very high copy number ( $>200$ in the case of pUC vectors), its gene product is present in too great an excess compared with the chromosomally encoded DnaK 756 protein, which results in the inability to grow at high temperatures. An alternative explanation of these results is that the burden imposed upon the host cells, caused by the DNA replication, transcription and translation associated with high-copy-number plasmids, may be just too much for the cell's machinery to cope with. Preliminary evidence to support the latter comes from our observation that $E$. coli $\mathrm{K} 756$ containing pUC19, or recombinant plasmids based on this vector, do not grow well even at $42{ }^{\circ} \mathrm{C}$. In contrast $E$. coli $\mathrm{K} 756$ containing pBR322, or recombinant plasmids based on this vector, grows well at $42^{\circ} \mathrm{C}$ (Table 3).

\section{Conclusions}

We have identified a new gene, $h \operatorname{tg} A$, which is required for high-temperature growth of $E$. coli. The $E$. coli dnaK null mutant BB1553 must have a mutation/deletion in this gene as well as in dnaK. Previous workers have probably missed the presence of the $h t g A$ gene because of the way in which they tested for genetic complementation of $d n a K$ mutants using P1 transduction with the $t h r$ marker located upstream of both the $d n a K$ and the $h t g A$ genes. Our results with $E$. coli $\mathrm{K} 756$ suggest that this strain may also have a defective $h \operatorname{tg} A$ gene. We are currently attempting to confirm that the $\operatorname{htg} A$ gene is defective in both $E$. coli $\mathrm{BB} 1553$ and $\mathrm{K} 756$ and sequencing the wild-type $h \operatorname{tg} A$ gene. It will be interesting to observe whether this gene has a characteristic heatshock promoter and whether it has any sequence homology to any other heat-shock genes.

D.O.D. was the recipient of an SERC studentship.

\section{References}

Bardwell, J. C. A. \& Craig, E. A. (1984). Major heat shock gene of Drosophila and Escherichia coli heat-inducible dnaK gene are homologous. Proceedings of the National Academy of Sciences of the United States of America 81, 848-852.

BukAu, B. \& Walker, G. C. (1989a). Cellular defects caused by deletion of the E. coli dna $K$ gene indicate roles for heat shock protein in normal metabolism. Journal of Bacteriology 171, 2337-2346.

BUKAU, B. \& WALKeR, G. C. $(1989 b)$. $\Delta d n a \mathrm{~K} 52$ mutants of $E$. coli have defects in chromosome segregation and plasmid maintenance at normal growth temperatures. Journal of Bacteriology 171, 6030-6038.

BUKAU, B. \& WalKer, G. C. (1990). Mutations altering heat shock specific subunit of RNA polymerase suppress major cellular defects of E. coli mutants lacking the DnaK chaperone. EMBO Journal 9 , 4027-4036.

CHAK, K.-F. \& JAMES, R. (1984). Localization and characterization of a gene on the ColE3-CA38 plasmid that confers immunity to colicin E8. Journal of General Microbiology 130, 701-710.

Chang, A. C. Y. \& Cohen, S. N. (1978). Construction and characterization of amplifiable multicopy DNA cloning vehicles derived from the P15A cryptic miniplasmid. Journal of Bacteriology 134, 1141-1156.

Ezaki, B., Ogura, T., Hironori, N. \& Hiraga, S. (1989). Involvement of DnaK protein in mini-F plasmid replication: temperaturesensitive seg mutations are located in the $d n a K$ gene. Molecular and General Genetics 218, 183-189.

GEORGOPOULOS, C. (1977). A new bacterial gene (groPC) which affects $\lambda$ DNA replication. Molecular and General Genetics 151, 35-39.

Georgopoulos, C. \& HerskowitZ, I. (1971). Escherichia coli mutants blocked in lambda DNA synthesis. In The Bacteriophage Lambda, pp. 553-564. Edited by A. D. Herschey. Cold Spring Harbor, NY: Cold Spring Harbor Laboratory.

Grossman, A. D., Straus, D. B., Walter, W. A. \& Gross, C. A. (1987). $\sigma^{32}$ synthesis can regulate the synthesis of heat shock proteins in E. coli. Genes and Development 1, 179-184.

Herendeen, S. L., Van Bogelan, R. A. \& Neidhardt, F. C. (1979) Levels of major proteins of $E$. coli during growth at different temperatures. Journal of Bacteriology 139, 185-194.

Ingolia, T. D., Slater, M. J. \& Craig, E. A. (1982). Saccharomyces cerevisae contains a complex multigene family related to the major heat shock-inducible gene of Drosophila. Molecular Cell Biology 2, 1388-1392.

Johnson, C., Chandresekhar, G. N. \& Georgopoulos, C. (1989). E. coli DnaK and GrpE heat shock proteins interact both in vivo and in vitro. Journal of Bacteriology 171, 1590-1596.

KaWASAKI, Y., WADA, C. \& YURA, T. (1990). Roles of E. coli heat shock proteins DnaK, DnaJ and GrpE in mini-F plasmid replication. Molecular and General Genetics 220, 277-282.

LibereK, K., Georgopoulos, C. \& ZYlicZ, M. (1988). Role of the DnaK and DnaJ heat shock proteins in the initiation of bacteriophage $\lambda$ DNA replication. Proceedings of the National Academy of Sciences of the United States of America 85, 6632-6636.

Lindquist, S. \& Craig, E. A. (1988). The heat shock proteins. Annual Review of Genetics 22, 631-677.

Maniatis, T., Fritsch, E. F. \& Sambrook. J. (1982). Molecular Cloning: a Laboratory Manual. Cold Spring Harbor, NY: Cold Spring Harbor Laboratory.

MerRick, M. J., Gibbins, J. R. \& Postgate, J. R. (1987). A rapid and efficient method of plasmid transformation of Klebsiella pneumoniae and Escherichia coli. Journal of General Microbiology 133, 2053-2057.

Miller, J. H. (1972). Experiments in Molecular Genetics. Cold Spring Harbor, NY: Cold Spring Harbor Laboratory.

Neidhard, F. C. \& VAN Bogelen, R. A. (1981). Positive regulatory gene for temperature-controlled proteins in E. coli. Biochemical and Biophysical Research Communications 100, 894-900.

PAeK, K.-H. \& WAlKer, G. C. (1987). E. coli dnaK null mutants are inviable at high temperature. Journal of Bacteriology 169, 283-290.

SAITo, H. \& UCHIDA, H. (1977). Initiation of the DNA replication of bacteriophage lambda in E. coli K12. Journal of Molecular Biology 113, 1-25. 
Tilly, K. \& Yarmolinsky, M. (1989). Participation of E. coli heat shock proteins DnaJ, DnaK and GrpE in Pl plasmid replication. Journal of Bacteriology 171, 6025-6029.

Vieira, J. \& Messing, J. (1982). The pUC plasmids, an M13mp7 derived system for insertion mutagenesis and sequencing with synthetic universal primers. Gene 19, 259-268.

WADSWORTH, S. C. (1982). A family of related proteins is encoded by the major Drosophila heat shock gene family. Molecular Cell Biology 2. $286-292$.

WICKNER, S. H. (1990). Three $E$. coli heat shock proteins are required for $\mathrm{Pl}$ plasmid DNA replication: formation of an active complex between $E$. coli DnaJ protein and the $\mathrm{Pl}$ initiator protein.
Proceedings of the National Academy of Sciences of the United States of America 87, 2690-2694

YAMAMORI, T. \& YURA, T. (1982). Genetic control of heat-shock protein synthesis and its bearing on growth and thermal resistance in E. coli K 12. Proceedings of the National Academy of Sciences of the United States of America 79, 860-864.

ZYLICZ, M., ANG, D. \& GEORGOPOULOS, C. (1987). The grpE protein of E. coli. Journal of Biological Chemistry 62, 17437-17442.

Zylicz, M., ANG, D., Liberek, K. \& Georgopoulos, C. (1989). Initiation of $\lambda$ DNA replication with purified host and bacteriophage-encoded proteins: the role of the DnaK, DnaJ and GrpE heat shock proteins. EMBO Journal 8, 1601-1608. 